\title{
Origin of Polarisation Losses in Solid Oxide Electrolysis Cells Operated at High Current Density
}

Knibbe, Ruth; Ebbesen, Sune; Mogensen, Mogens Bjerg

Published in:

Meeting Abstracts - Electrochemical Society

Publication date:

2010

Document Version

Publisher's PDF, also known as Version of record

Link back to DTU Orbit

Citation (APA):

Knibbe, R., Ebbesen, S., \& Mogensen, M. B. (2010). Origin of Polarisation Losses in Solid Oxide Electrolysis

Cells Operated at High Current Density. In Meeting Abstracts - Electrochemical Society (pp. Abstract 1338). The Electrochemical Society.

\section{General rights}

Copyright and moral rights for the publications made accessible in the public portal are retained by the authors and/or other copyright owners and it is a condition of accessing publications that users recognise and abide by the legal requirements associated with these rights.

- Users may download and print one copy of any publication from the public portal for the purpose of private study or research.

- You may not further distribute the material or use it for any profit-making activity or commercial gain

- You may freely distribute the URL identifying the publication in the public portal 
Origin of polarisation losses in solid oxide electrolysis cells operated at high current density

R. Knibbe, S. D. Ebbesen \& M. Mogensen Fuel Cells and Solid State Chemistry Division Risø National Laboratory for Sustainable Energy Technical University of Denmark 4000 Roskilde, Denmark

Solid oxide electrolysis cells (SOEC) are being increasingly investigated as a means of producing hydrogen or synthesis gas. The SOEC has the same configuration as a standard solid oxide fuel cell (SOFC), but a current is applied rather than drawn (Figure 1). When SOECs are operated under high current density, the area specific resistance (ASR) increases. However, when the same cells are operated under a SOFC current, the ASR decreases (Figure 1, 2) [1].

For an economic point of view, operation at high current (up to $\sim 2 \mathrm{~A} / \mathrm{cm}^{2}$ ) is interesting to increase the production rate of either hydrogen or synthesis gas [2]. It is therefore of interest to understand the origin of the increased polarisation and degradation behaviour of the cell [3].

Preliminary impedance analysis of fuel electrode supported full cells during electrolysis operation and subsequent modelling suggests that the electrochemical polarisation increase is due to both fuel electrode and the oxygen electrode increases. Under full cell testing, the electrochemical information from the two respective electrodes can be separated by using gas shift impedance. However, the high operating temperatures involved with this work makes it difficult to accurately ascribe processes to the fuel electrode or the oxygen electrode (Figure 1) [4]. Therefore it is of interest to study the effect of the anodic polarisation on $(\mathrm{La}, \mathrm{Sr}) \mathrm{MnO}_{3}(\mathrm{LSM})-\mathrm{Y}_{2} \mathrm{O}_{3}-\mathrm{ZrO}_{2}$ Zirconia (YSZ) and cathodic polarisation on Ni-YSZ using 3 electrode pellet studies.

The effect of current density on the cell polarisation and cell degradation will be discussed based on both full $\mathrm{Ni} /$ YSZ- YSZ- LSM/YSZ cells and LSM/YSZ electrode response from 3 electrode pellet.

\section{REFERENCES}

1. Marina, O.A., et al., Electrode performance in reversible solid oxide fuel cells. Journal of the Electrochemical Society, 2007. 154(5): p. B452B459.

2. Jensen, S.H., P.H. Larsen, and M. Mogensen, Hydrogen and synthetic fuel production from renewable energy sources. International Journal of Hydrogen Energy, 2007. 32(15): p. 32533257.

3. Hauch, A., et al., Performance and durability of solid oxide electrolysis cells. Journal of the Electrochemical Society, 2006. 153(9): p.

A1741-A1747.

4. Brisse, A., J. Schefold, and M. Zahid, High temperature water electrolysis in solid oxide cells. International Journal of Hydrogen Energy, 2008. 33(20): p. 5375-5382.

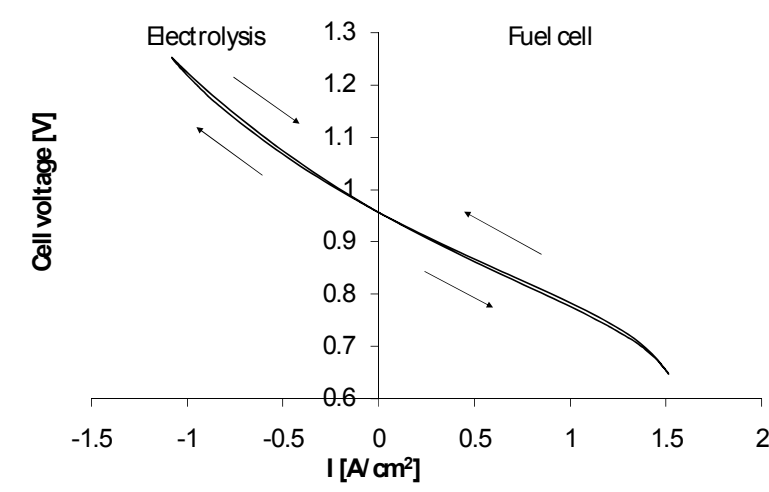

Figure 1: Current-Voltage curve for solid oxide cell operated at $850^{\circ} \mathrm{C}$ with 50:50 steam:hydrogen gas supplied to the fuel electrode and oxygen supplied to the oxygen electrode.

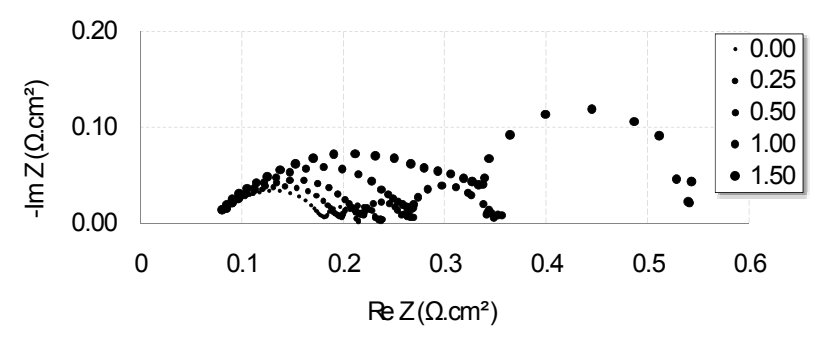

Figure 2: Impedance spectra of SOEC cell operated at $850^{\circ} \mathrm{C}$ with 50:50 steam:hydrogen gas supplied to the fuel electrode and oxygen supplied to the oxygen electrode under increasing electrolysis current $0,0.25,0.50,1,1.50 \mathrm{~A} / \mathrm{cm}^{2}$. 